University of Nebraska - Lincoln

DigitalCommons@University of Nebraska - Lincoln

Publications from USDA-ARS / UNL Faculty

U.S. Department of Agriculture: Agricultural

Research Service, Lincoln, Nebraska

2008

Heterosis in Switchgrass: Biomass Yield in Swards

Kenneth P. Vogel

University of Nebraska-Lincoln, kvogel1@unl.edu

Rob B. Mitchell

USDA-ARS, rob.mitchell@ars.usda.gov

Follow this and additional works at: https://digitalcommons.unl.edu/usdaarsfacpub

Vogel, Kenneth P. and Mitchell, Rob B., "Heterosis in Switchgrass: Biomass Yield in Swards" (2008).

Publications from USDA-ARS / UNL Faculty. 1960.

https://digitalcommons.unl.edu/usdaarsfacpub/1960

This Article is brought to you for free and open access by the U.S. Department of Agriculture: Agricultural Research Service, Lincoln, Nebraska at DigitalCommons@University of Nebraska - Lincoln. It has been accepted for inclusion in Publications from USDA-ARS / UNL Faculty by an authorized administrator of DigitalCommons@University of Nebraska - Lincoln. 


\title{
Heterosis in Switchgrass: Biomass Yield in Swards
}

\author{
Kenneth P. Vogel` and Rob B. Mitchell
}

\begin{abstract}
Improving the biomass yield of switchgrass (Panicum virgatum L.) will improve its utility as a dedicated energy crop by increasing both its net and total energy yield per hectare. In a previous space-transplanted study, midparent heterosis for biomass yield was reported for population and specific $F_{1}$ hybrids of the lowland-tetraploid cultivar Kanlow and the upland-tetraploid cultivar Summer. These two cultivars were proposed to be two different heterotic groups. The objective of this study was to determine the extent of heterosis for biomass yield in reciprocal Kanlow (K) and Summer $(S) F_{1}$ population hybrids grown in simulated swards and to determine the effect of advance in generation on biomass yield. Parent populations and their $F_{1}, F_{2}$, and $F_{3}$ population hybrids were grown in transplanted sward plots located near Mead, NE, for a three-year period. Plant density in the simulated swards was equivalent to acceptable stands in seeded plots. Plots were not harvested the establishment year to enable them to become fully established. Biomass yields were determined for the following two years. There was significant high-parent heterosis of 30 to $38 \%(P \leq 0.01)$ for biomass yield for both the $\mathrm{K} \times \mathrm{S} \mathrm{F}_{1}$ and $\mathrm{S} \times \mathrm{KF}_{1}$ hybrid populations. Heterosis for biomass yield declined with advance in generation. Heterosis for biomass yield in switchgrass may need the competitive conditions of swards to be fully expressed. Additional trials of specific hybrids established from seed are needed to further verify these conclusions. These results do provide ample justification for additional research to develop switchgrass population and specific hybrids.
\end{abstract}

USDA-ARS, 314 Biochemistry Hall, Univ. of Nebraska, P.O. Box 830737, Lincoln, NE 68583-0737. Mention of trade names or commercial products is solely for the purpose of providing specific information and does not imply recommendation or endorsement by the U.S. Department of Agriculture. Received 29 Feb. 2008. *Corresponding author (Ken.Vogel@ars.usda.gov).

Abbreviations: ARDC, Agriculture Research and Development Center; K, Kanlow; PAR, Plant Adaptation Region; S, Summer.

Cwitchgrass (Panicum virgatum L.) is being developed as a bio$\checkmark$ mass energy crop in the United States for use on marginal cropland (McLaughlin and Kszos, 2005). Improving biomass yield of switchgrass will improve its utility as a dedicated energy crop by increasing both its net and total energy yield per hectare and its potential profitability (Perrin et al., 2008; Schmer et al., 2008). All switchgrass cultivars that have been developed to date are improved populations or synthetic cultivars that were developed using breeding methods that utilize additive genetic variation (Vogel and Pedersen, 1993; Vogel, 2000, 2004). Grass breeders have not utilized nonadditive genetic variance to produce hybrid cultivars except where the hybrids can be propagated asexually or via apomictic mechanisms (Burton, 1989; Vogel, 2000; Vogel and Burson, 2004). Effective mechanisms to emasculate or control pollination at the seed production field scale and lack of information on heterotic groups and extent of heterosis has delayed the effective use of hybrid cultivars for most perennial grass forage and biomass species including switchgrass.

Switchgrass has two distinct ecotypes, lowland and upland, and two major ploidy levels, tetraploid $(2 n=4 x=36)$ and

Published in Crop Sci. 48:2159-2164 (2008).

doi: 10.2135/cropsci2008.02.0117

(C) Crop Science Society of America

677 S. Segoe Rd., Madison, WI 53711 USA

All rights reserved. No part of this periodical may be reproduced or transmitted in any form or by any means, electronic or mechanical, including photocopying, recording, or any information storage and retrieval system, without permission in writing from the publisher. Permission for printing and for reprinting the material contained herein has been obtained by the publisher. 
octaploid $(2 n=8 x=72)$ (Vogel, 2004). Switchgrass has two cytoplasm types, $\mathrm{L}$ and $\mathrm{U}$, based on chloroplast DNA polymorphisms that are associated with the lowland and upland ecotypes, respectively (Hultquist et al., 1996; Missaoui et al., 2006). Martinez-Reyna and Vogel (2008) have reported the existence of midparent heterosis for biomass yield in switchgrass grown in space-transplanted nurseries and identified lowland-tetraploid and upland-tetraploid switchgrasses as heterotic groups. Switchgrass is grown in swards as a pasture and biomass energy crop. MartinezReyna and Vogel (2008) pointed out that the extent of heterosis in switchgrass for biomass yield in sward conditions and the effect of advance in generation on heterosis needed to be determined. In their study, the lowland-tetraploid cultivar Kanlow and the upland-tetraploid cultivar Summer were identified as being in different heterotic groups. Kanlow originates from plant material collected near Wetumka, OK, with additional selection work at Manhattan, KS (Alderson and Sharp, 1994). Summer originates from plant material collected south of Nebraska City, NE (Alderson and Sharp, 1994). Mass selection was then conducted at Brookings, SD, for earliness, leafiness, and rust resistance. Kanlow's origin is in upper Plant Hardiness Zone 7 whereas Summer's origin is in Plant Hardiness Zone 5 (Alderson and Sharp, 1994; Vogel et al., 2005). Winter survival of Kanlow at Mead, NE, has been a problem, with substantial winterkill occurring in some years. These results are consistent with recently published adaptation information for switchgrass (Casler et al., 2004, 2007) that demonstrates that survival of switchgrass cultivars may be a problem if they are moved more than a hardiness zone north of their origin hardiness zone.

In previous heterosis research on alfalfa (Medicago sativa L.), Bingham et al. (1994) suggested that while maximum heterosis is reached in diploids in one generation $\left(\mathrm{S}_{1}\right.$ or $\mathrm{F}_{1}$ ), heterosis is progressive in tetraploid alfalfa and is not reached until the double cross $\left(\mathrm{S}_{2}\right)$ or later generations, probably due to complementary gene action or epistasis. Molecular marker analyses of the genomic structure of tetraploid switchgrass indicate that it is an autopolyploid, but the results are not unequivocal (Missaoui et al., 2005). In constrast to alfalfa, switchgrass tetraploids segregate as diploids (Vogel, 2004). The effect of advance in generation on heterosis in tetraploid switchgrasses has not been previously investigated.

The objective of this study was to determine the extent of heterosis for biomass yield in reciprocal lowland-tetraploid (Kanlow) and upland-tetraploid (Summer) hybrids of switchgrass grown in simulated swards and to determine the effect of advance in generation on heterosis for biomass yield. High-parent heterosis is defined as the positive difference between the mean of the hybrid and the mean of the best parent for specific traits, while midparent heterosis is the positive difference between the hybrid and the mean of the two parents (Lamkey and Edwards, 1999). Population or panmictic high-parent heterosis occurs when two random-mated populations are intermated to form an $F_{1}$ hybrid and the mean of the $F_{1}$ hybrid population exceeds the mean of the best-parent population (Lamkey and Edwards, 1999). The hybrids evaluated in this study are population hybrids.

\section{MATERIALS AND METHODS}

The switchgrass cultivars and population hybrids used in this study are summarized in Table 1. Kanlow and Summer have been fully described above. The strains listed as $\mathrm{F}_{2}$ or $\mathrm{F}_{3}$ generation in Table 1 also could be described as Syn 2 (second generation of synthesis or random mating) or Syn 3 generations, respectively, using the terminology commonly used by forage breeders to designate generations of propagation for synthetic populations (Fehr, 1991). A synthetic is a population produced by intermating selected genotypes, usually in isolation, from other plants of the same species and which is propagated by random mating from generation to generation (Fehr, 1991). 'Shawnee' was released in 1995 and is an upland octaploid cultivar that was developed for use in pastures and potentially for biomass energy (Vogel et al., 1996).

Kanlow N1 is a synthetic population based on 72 Kanlow genotypes that were selected for winter survival at the University of Nebraska's Agriculture Research and Development Center (ARDC) located near Mead, NE, where we have our main breeding nurseries and where this study was conducted. A 400-plant, space-transplanted evaluation nursery of Kanlow was established in 1995 at the ARDC. Because of winterkill that occurred in this nursery during the winters of 1995-1996, 1996-1997, and 1997-1998, this nursery was converted into a winter-survival selection nursery. Surviving plants that were nonlodged and visually had good vigor the previous growing season were identified in early December 1998. After spring green-up in 1999, two ramets from each of 57 surviving genotypes from this nursery were transplanted into an isolated polycross nursery along with two ramets from each of 15 other Kanlow plants that had survived two winters in another nursery to form the Kanlow N1 population. A ramet is a member of a clone. Within the polycross nursery, the ramets were transplanted at random on 1.1-m centers. The intent of including Kanlow N1 in this study was to use it as the high-parent control if winterkill occurred in the parent Kanlow plots during the duration of the field sward trial. The Kanlow N1 polycross nursery and the other polycross nurseries described below were spatially isolated from other switchgrass nurseries at the ARDC by a minimal distance of $400 \mathrm{~m}$. Syn 1 seed harvested from this polycross nursery in 2000 was used in this study.

The $F_{1}$ hybrid plants used in this study were from crosses described by Martinez-Reyna and Vogel (2008). None of the parent Kanlow or Summer plants used to produce the $F_{1}$ plants were selected. The parent plants were grown from seedlings in a greenhouse where the crossing and $F_{1}$ seed production occurred. Extra $F_{1}$ seedlings not needed in the spaced-transplanted heterosis experiments described by Martinez-Reyna and Vogel (2008) were transplanted into a field nursery in 1997 and maintained there until the initial biomass yield results were 
Table 1. Switchgrass parent and check cultivars, population hybrids, and their advanced generations used to determine the extent of heterosis for biomass yield in switchgrass grown in simulated sward plots and effect of generation advance on heterosis.

\begin{tabular}{|c|c|c|}
\hline Strain & Description & Source \\
\hline 'Kanlow' (K) & Released lowland-tetraploid cultivar & Foundation seed, USDA-NRCS Plant Materials Cent., Manhattan, KS \\
\hline 'Summer' (S) & Released upland-tetraploid cultivar & Foundation seed, South Dakota State Univ., Brookings \\
\hline Kanlow N1 & Selection from Kanlow for winter survival at Mead, NE & Syn 1 seed from polycross of selected plants ${ }^{\dagger}$ \\
\hline $\mathrm{K} \times \mathrm{SF}_{1}$ & $F_{1}$ plants of $\mathrm{K}\left({ }^{\Uparrow}\right) \times \mathrm{S}(P)$ crosses (Martinez-Reyna \& Vogel, 2008) $)^{\ddagger}$ & $F_{1}$ generation \\
\hline $\mathrm{S} \times \mathrm{KF}_{1}$ & $F_{1}$ plants of $S(\widehat{)}) \times K(P)$ crosses (Martinez-Reyna \& Vogel, 2008) & $\mathrm{F}_{1}$ generation \\
\hline $\mathrm{K} \times \mathrm{SF}_{2}$ & $\mathrm{~F}_{2}$ or Syn 2 population from $\mathrm{K} \times \mathrm{S}$ population cross & $\begin{array}{l}\mathrm{F}_{2} \text { seed produced from ramets of } \mathrm{K} \times \mathrm{SF}_{1} \text { plants grown in an } \\
\text { isolated polycross }\end{array}$ \\
\hline $\mathrm{S} \times \mathrm{KF}_{2}$ & $\mathrm{~F}_{2}$ or Syn 2 population from $\mathrm{S} \times \mathrm{K}$ population cross & $\begin{array}{l}\mathrm{F}_{2} \text { seed produced from ramets of } \mathrm{S} \times \mathrm{KF}_{1} \text { plants grown in an } \\
\text { isolated polycross }\end{array}$ \\
\hline $\mathrm{K} \times \mathrm{SF}_{3}$ & $\mathrm{~F}_{3}$ or Syn 3 population from $\mathrm{K} \times \mathrm{S}$ population cross & $\mathrm{F}_{3}$ seed produced from $\mathrm{F}_{2}$ plants grown in an isolated polycross \\
\hline $\mathrm{S} \times \mathrm{KF}_{3}$ & $\mathrm{~F}_{3}$ or Syn 3 population from $\mathrm{S} \times \mathrm{K}$ population cross & $\mathrm{F}_{3}$ seed produced from $\mathrm{F}_{2}$ plants grown in an isolated polycross \\
\hline 'Shawnee’ & Upland-octaploid released cultivar & Certified seed \\
\hline
\end{tabular}

†Syn 1, Syn 2, and Syn 3 represent the first, second, and third generations, respectively, of synthesis or random mating.

$\neq \hat{\delta}, \underline{q}=$ male and female, respectively.

obtained from those experiments. In the spring of 1999, ramets from the plants in these nurseries were moved to polycross nurseries to initiate the generation advance component of this study. The Kanlow $\times$ Summer $(\mathrm{K} \times \mathrm{S}) \mathrm{F}_{1}$ polycross nursery comprised two ramets each of 51 genotypes from 11 different $\mathrm{K} \times \mathrm{S}$ crosses. The Summer $\times$ Kanlow $(\mathrm{S} \times \mathrm{K}) \mathrm{F}_{1}$ polycross nursery comprised two ramets each of $59 \mathrm{~F}_{1}$ genotypes that originated from 13 different $\mathrm{K} \times \mathrm{S}$ crosses. The same polycross procedures described previously for the Kanlow N1 populations were used. The polycrosses of the $\mathrm{K} \times \mathrm{S}$ and $\mathrm{S} \times \mathrm{K} \mathrm{F}_{1}$ plants produced $\mathrm{F}_{2}$ seed in 1999 that was used to start seedlings in the greenhouse in the spring of 2000 , which were used to establish 600-plant polycross nurseries for the production of $\mathrm{F}_{3}$ seed in the autumn of 2000. The $F_{2}$ seed used in this study was also from the 2000 harvest. Although no winterkill of plants was observed by Martinez-Reyna and Vogel (2008) in their study, the extent of winterkill in the Kanlow selection nursery described above raised concerns. To have equivalent plant material to compare with the Kanlow N1 population, the plants moved to the $\mathrm{F}_{1}$ polycross nurseries met the same criteria as the plants used to produce the Kanlow N1 population, with the exception that there was no apparent winter injury to any of the plants.

The strains listed in Table 1 were grown in a simulated sward nursery in a transplanted, replicated trial at Mead, NE. All entries except for the $F_{1}$ generation were started as seedlings in the greenhouse. Seeds were planted in cone-tainers (Stuewe \& Sons, Inc., Corvallis, OR) $21 \mathrm{~cm}$ deep and $4 \mathrm{~cm}$ in diameter, filled with a mixture of soil, peat, and vermiculite (2:1:1 volume ratio) in a greenhouse with an 18-h photoperiod and a mean temperature of $28^{\circ} \mathrm{C}$. After emergence, seedlings were thinned to one per cone-tainer and were maintained in the greenhouse until they were transplanted to the field. The $\mathrm{F}_{1}$ plants used in the study were obtained by collecting an equal number of micro-ramets from each of the $\mathrm{F}_{1}$ plants in the $\mathrm{K} \times$ $\mathrm{S}$ and $\mathrm{S} \times \mathrm{K}$ polycross nurseries that were established in 1999 . Micro-ramets of the $\mathrm{F}_{1}$ plants were used so that there was $100 \%$ complete direct lineage from $\mathrm{F}_{1}$ to $\mathrm{F}_{2}$ and $\mathrm{F}_{3}$ in the field evaluation trial. The micro-ramets were about $3.5 \mathrm{~cm}$ in diameter and $10 \mathrm{~cm}$ deep and were dug from the nurseries in the spring of
2001. They were transplanted into small greenhouse pots and were held in a greenhouse under similar conditions as the seedlings until all seedlings and micro-ramets were transplanted into the field nursery.

Seedlings and micro-ramets were transplanted into a field evaluation nursery located near Mead, NE, on 6 June 2001. A field plot consisted of plants transplanted on $0.3-\mathrm{m}$ centers in a 4 by 8 arrangement. This plant density has been demonstrated to be an adequate sward stand for switchgrass grown as either a pasture or biomass crop in research spanning several decades (Launchbaugh and Owensby, 1970; Vogel, 1987; Schmer et al., 2006). This stand density also is supported by the comprehensive ecological studies of Weaver (1968), which spanned a 50-yr period. The basal cover occupied by grasses in tallgrass prairies of the United States was $<15 \%$ (Weaver, 1968).

A border row of switchgrass seedlings were transplanted on the edges of the nursery at the same plant density and spacing to eliminate border effects. The experimental design was a randomized complete block with four replicates. No fertilizers were applied the establishment year. In the postestablishment years, the study was fertilized in the spring with $112 \mathrm{~kg} \mathrm{ha}^{-1} \mathrm{~N}$ $\left(\mathrm{NH}_{4} \mathrm{NO}_{3}\right)$. Herbicides and hand-weeding were used for weed control. One week after transplanting, atrazine (6-chloro- $N$ ethyl- $N$-isopropyl-1,3,5,-triazine-2,4-diamine) and quinclorac (3,7-dichloro-8-quinolinecarboxylic acid) were applied at a rate of 2.24 and $0.56 \mathrm{~kg} \mathrm{ha}^{-1}$, respectively. In the spring of the postestablishment years, atrazine, metolachlor [2-chloro- $\mathrm{N}-(2-$ ethyl-6-methylphenyl)-N-(2-methoxy-1-methyl) acetamide], and 2,4-D (2,4-dichlorophenoxyacetic acid) were applied at a rate of $2.24,2.12$, and $1.12 \mathrm{~kg} \mathrm{ha}^{-1}$, respectively. No data were collected the establishment year. In 2002 and 2003, the residual biomass on the plots from the previous year was removed by burning before spring growth was initiated. Entire plots were harvested for biomass yield on 14 Aug. 2002 and 18 Aug. 2003 with a plot flail harvester with a cutting height of $10 \mathrm{~cm}$. Plots were measured for plant height (height to top of panicle) before harvest in 2002. Plots were sampled before harvest to determine dry matter concentration. Wet sample weights were added to plot yields to nullify the effect of subsample size on biomass yield. Yields are reported on a dry-weight basis. Harvested area 
was $3 \mathrm{~m}^{2}$. Stands were determined after harvest by counting the number of surviving harvested plants in each plot. All plots were at reproductive maturity stages when visually assessed before biomass yield harvest using the Nebraska system described by Moore et al. (1991). The single harvest treatment, harvest time, and $\mathrm{N}$ fertilization rates used in this study are based on the results of Vogel et al. (2002).

All data were analyzed using the GLM procedure of PCSAS software (SAS Institute, 2002). Strain or populations were considered to be fixed effects. Because with perennials, mean performance over years is of primary importance, plot means over years were used in ANOVA for plant biomass yield. A split-plot-in-time ANOVA (data not shown) was conducted to assess the magnitude of year and genotype $\times$ year effects on biomass yield. Protected LSD values were used to make mean comparisons and to test for significance of high-parent heterosis expressed as a mean difference or deviation. For statistical tests, heterosis is best expressed as a deviation from either the midparent (midparent heterosis) or best-parent mean (high-parent heterosis), which permits the use of mean comparison statistics such as the LSD for comparing mean differences between hybrids and their parents (Lamkey and Edwards, 1999). Highparent heterosis values also are expressed as a percentage, but the statistical tests were made using mean differences.

\section{RESULTS AND DISCUSSION}

A full growing season was utilized to enable the plants in the simulated swards trials to become well established before any harvests were made. There were no significant differences among strains for stands (number of plants per plot). The mean number of plants per $3-\mathrm{m}^{2}$ plot was 30. For readers unfamiliar with switchgrass, by the second year after being transplanted as seedlings, individual switchgrass plants typically have a diameter of $20 \mathrm{~cm}$ or more. The calculated basal cover area exceeded 30\%, which is double that reported by Weaver (1968) for tallgrass prairie. During the period of this trial, there was no apparent winter damage or winterkill for any of the plants in the plots.

There were significant differences $(P \leq 0.01)$ among strains for biomass yield for the two harvest years (Table $2)$. The highest yielding strains in the nursery were the two $\mathrm{F}_{1}$ population hybrids $\left(\mathrm{K} \times \mathrm{S} \mathrm{F}_{1}\right.$ and $\left.\mathrm{S} \times \mathrm{K} \mathrm{F}_{1}\right)$. The Kanlow N1 population had numerically greater mean biomass yield over the two harvest years than Kanlow, but the differences were not statistically different. The Kanlow N1 strain was used as the high parent in the heterosis calculations because its greater biomass yield provided a more rigorous test of high-parent heterosis. It will be the Kanlow germplasm source that will be used in our program for hybrids for the central latitudes of the United States because of prior selection for winter survival. There was significant high-parent heterosis $(P \leq 0.01)$ for biomass yield for both the $\mathrm{K} \times \mathrm{S} \mathrm{F}_{1}$ and $\mathrm{S} \times \mathrm{K} \mathrm{F}_{1}$ hybrid populations. There was also significant $\mathrm{F}_{1}$ heterosis for plant height, which was measured only in 2003. Kanlow and
Kanlow N1 were similar in maturity and were the latest maturing strains in the test. Summer and Shawnee were similar in maturity and were the earliest maturing strains. The $\mathrm{F}_{1}, \mathrm{~F}_{2}$, and $\mathrm{F}_{3} \mathrm{~K} \times \mathrm{S}$ and $\mathrm{S} \times \mathrm{K}$ populations were intermediate in maturity to their two parents. The earlier maturity of Summer and Shawnee in comparison to the lowland and lowland $\times$ upland hybrids likely was a factor that was in part responsible for their lower yields.

Heterosis for biomass yield declined with advance in generation (Table 2). The $\mathrm{F}_{2}$ and $\mathrm{F}_{3}$ populations were significantly lower in biomass yield than the $F_{1}$ populations and were typically intermediate to the parents in biomass yield. The only inconsistency that did not conform to expected results was that the $\mathrm{K} \times \mathrm{S} \mathrm{F}_{3}$ population had a greater biomass mean yield than $\mathrm{F}_{2}$ population of the same population hybrid. Although tetraploid switchgrass has been tentatively classified as an autotetraploid, its decline in heterosis for biomass yield is more similar to that of diploid species than autotetraploid alfalfa.

The results of the trial were consistent over the two years even though there were large significant year effects due to differences in rainfall during the growing season (analyses not shown). In 2002 and 2003, the annual precipitation was 646 and $651 \mathrm{~mm}$, respectively, but the precipitation during May, June, and July were $161 \mathrm{~mm}$ in 2002 when drought conditions existed vs. $250 \mathrm{~mm}$ in 2003. Plant height measurements were not taken in 2002 because of the drought conditions. The relative ranking of the strains were stable over the two years with only minor changes in ranking. The Spearman rank correlation of 2002 and 2003 biomass yields with the $2-y r$ mean yields was 0.86 and 0.89 $(P \leq 0.01)$, respectively. The Mead location is representative of the Plant Adaptation Region (PAR) 251-HZ5, which encompasses most of the midwestern United States (Vogel et al., 2005). The use of PARs for defining switchgrass adaptation regions has been demonstrated by Casler et al. (2007). In this region, genotype $\times$ environment interaction effects exist for biomass yield of switchgrass, but the best cultivars rank at the top of trials across multiple environments (Hopkins et al., 1995). Although these results are from a single location, the Mead location is predictive of switchgrass yields throughout the midwestern United States (Hopkins et al., 1995).

The results of this study demonstrate that under the competitive conditions that exist under simulated swards, high-parent heterosis for biomass yields exists for switchgrass hybrids developed from the tetraploid-lowland and tetraploid-upland heterotic groups represented by Kanlow and Summer, respectively. These results substantiate the previous identification of these populations as heterotic groups by Martinez-Reyna and Vogel (2008). High-parent heterosis for biomass yield did not occur in the space-planted trials reported previously (Martinez-Reyna and Vogel, 2008). Although the study reported by Martinez-Reyna 
Table 2. Mean biomass yield of 'Kanlow' and 'Summer' switchgrass, their reciprocal $F_{1}$ hybrids, and the $F_{2}$ and $F_{3}$ generations grown in simulated sward plots at Mead, NE, and high-parent heterosis for the $F_{1}$ hybrids expressed as a deviation from the high-parent mean.

\begin{tabular}{|c|c|c|c|c|c|c|c|}
\hline Strain & $\begin{array}{l}\text { Biomass } \\
\text { yield }\end{array}$ & $\begin{array}{c}\text { Biomass yield } \\
\text { heterosis } \\
\left(\mathrm{F}_{1}-\text { Kanlow } N 1\right)\end{array}$ & $\begin{array}{c}\text { Biomass yield } \\
\text { heterosis }\end{array}$ & $\begin{array}{l}\text { Plant } \\
\text { height }\end{array}$ & $\begin{array}{c}\text { Plant height } \\
\text { heterosis } \\
\left(\mathrm{F}_{1}-\text { Kanlow } \mathrm{N} 1\right)\end{array}$ & $\begin{array}{l}\text { Plant height } \\
\text { heterosis }\end{array}$ & $\begin{array}{c}\text { Maturity } \\
\text { stage }^{\dagger}\end{array}$ \\
\hline & \multicolumn{2}{|c|}{$\mathrm{Mg} \mathrm{ha}^{-1} \longrightarrow$} & $\%$ & \multicolumn{2}{|c|}{$\mathrm{cm}-$} & $\%$ & \\
\hline Kanlow (K) & 14.7 & & & 112 & & & 3.0 \\
\hline Summer (S) & 12.4 & & & 96 & & & 3.3 \\
\hline Kanlow N1 & 15.1 & & & 117 & & & 3.0 \\
\hline $\mathrm{K} \times \mathrm{SF}_{1}$ & 20.9 & $5.8^{*}$ & 38 & 131 & $14^{*}$ & 12 & 3.2 \\
\hline $\mathrm{S} \times \mathrm{KF} \mathrm{F}_{1}$ & 19.7 & $4.6^{\star}$ & 30 & 139 & $22^{*}$ & 19 & 3.2 \\
\hline $\mathrm{K} \times \mathrm{SF}_{2}$ & 13.8 & & & 112 & & & 3.2 \\
\hline $\mathrm{S} \times \mathrm{KF}_{2}$ & 14.6 & & & 111 & & & 3.2 \\
\hline $\mathrm{K} \times \mathrm{SF}_{3}$ & 15.4 & & & 114 & & & 3.2 \\
\hline $\mathrm{S} \times \mathrm{KF}_{3}$ & 11.7 & & & 105 & & & 3.2 \\
\hline 'Shawnee' & 13.9 & & & 100 & & & 3.3 \\
\hline LSD 0.05 & 2.9 & 2.9 & & 14 & 14 & & 0.1 \\
\hline$F$ ratio from ANOVA & $4.31^{\star \star}$ & & & $7.46^{\star \star}$ & & & 33.5 \\
\hline
\end{tabular}

*Significant at the 0.05 level of probability.

${ }^{* *}$ Significant at the 0.01 level of probability.

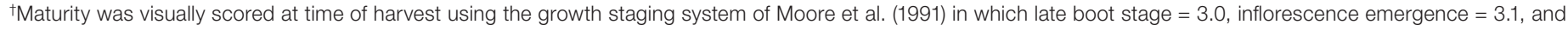
panicle fully emerged but peduncle not emerged $=3.3$.

and Vogel (2008) and this study occurred in different time periods, 1996 to 1999 and 1999 to 2003, respectively, they were conducted in fields with similar soils that were about $1 \mathrm{~km}$ apart. Hence, it is reasonable to compare the results. In space-transplanted conditions where the plants were on 1.1-m centers, only midparent heterosis was expressed. Under the simulated sward conditions of this study with 10 plants $\mathrm{m}^{-2}$, greater parent heterosis was expressed. Heterosis for biomass yield in switchgrass may need the competition associated with sward conditions to be fully expressed. In maize (Zea mays L.), the effect of high plant densities on the expression of heterosis for yield is well documented. The effects of sward conditions on the expression of heterosis for biomass yield for switchgrass is opposite that which has been reported for perennial ryegrass (Lolium perenne L.) (Foster, 1971a,b). Switchgrass differs from perennial ryegrass by many plant characteristics, and the difference in heterosis response under sward conditions is not unexpected. The heterosis for biomass yield may be due in part to heterosis for plant height. The biomass yield results from the $\mathrm{F}_{2}$ and $\mathrm{F}_{3}$ populations demonstrate that to optimize biomass yields, commercial production fields need to be planted with $\mathrm{F}_{1}$ seed.

Additional trials of specific hybrids are still needed to further verify these conclusions, however, because production fields will not be transplanted. These results do provide ample justification for additional research to develop other populations and specific hybrids for seeded field trials. A seed production system for producing hybrid switchgrass seed was described previously as well as breeding procedures for developing the plant materials to be used to produce the hybrids (Martinez-Reyna and Vogel, 2008). We are currently engaged in this process by conducting selection for biomass yield, quality traits, and plant maturity with populations based on both Kanlow and Summer. The plant material from this current breeding generation will be used for the production of additional $F_{1}$ hybrids for seeded field trials. Research also needs to develop improved seed production technology and improving methods such as described by Alexandrova et al. (1996) to rapidly increase clones for transplanting into hybrid seed production fields before hybrid switchgrass becomes a commercial reality.

\section{References}

Alderson, J., and W.C. Sharp. 1994. Grass varieties in the United States. Agric. Handb. 170. USDA, Soil Conserv. Serv., Washington, DC.

Alexandrova, K.S., P.D. Denchev, and B.V. Conger. 1996. Micropropagation of switchgrass by node culture. Crop Sci. 36:1709-1711.

Bingham, E.T., R.W. Groose, D.R. Woodfield, and K.K. Kidwell. 1994. Complementary gene interactions in alfalfa are greater in autotetraploids than diploids. Crop Sci. 34:823-829.

Burton, G.W. 1989. Progress and benefits to humanity from breeding warm-season forage grasses. p. 21-29. In D.A. Sleper, K.H. Asay, and J.F. Pedersen (ed.) Contributions from breeding forage and turf grasses. CSSA Spec. Publ. 15. CSSA, Madison, WI.

Casler, M.D., K.P. Vogel, C.M. Taliaferro, N.J. Ehlke, J.D. Berdahl, E.C. Brummer, R.I. Kallenbach, C.P. West, and R.B. Mitchell. 2007. Latitudinal and longitudinal adaptation of switchgrass populations. Crop Sci. 47:2249-2260.

Casler, M.D., K.P. Vogel, C.M. Taliaferro, and R.E. Wynia. 2004. Latitudinal adaptation of switchgrass populations. Crop Sci. 44:293-303. 
Fehr, W.R. 1991. Principles of cultivar development. Vol. 1. Theory and technique. Macmillan, New York.

Foster, C.A. 1971a. Interpopulation and intervarietal F1 hybrids in Lolium perenne: Heterosis under simulated sward conditions. J. Agric. Sci. 76:401-409.

Foster, C.A. 1971b. Interpopulation and intervarietal hybridization in Lolium perenne breeding: Heterosis under non-competitive conditions. J. Agric. Sci. 76:107-130.

Hopkins, A.A., K.P. Vogel, K.J. Moore, K.D. Johnson, and I.T. Carlson. 1995. Genotype effects and genotype by environment interactions for traits of elite switchgrass populations. Crop Sci. 35:125-132.

Hultquist, S.J., K.P. Vogel, D.J. Lee, K. Arumuganathan, and S. Kaeppler. 1996. Chloroplast DNA and nuclear DNA content variations among cultivars of switchgrass, Panicum virgatum L. Crop Sci. 36:1049-1052.

Lamkey, K.R., and J.W. Edwards. 1999. Quantitative genetics of heterosis. p. 31-48. In J.G. Coors and S. Pandey (ed.) Genetics and exploitation of heterosis in crops. ASA and CSSA, Madison, WI.

Launchbaugh, J.L., and C.E. Owensby. 1970. Seeding rate and first-year stand relationships for six native grasses. J. Range Manage. 23:414-417.

Martinez-Reyna, J.M., and K.P. Vogel. 2008. Heterosis in switchgrass: Spaced plants. Crop Sci. 48:1312-1320.

McLaughlin, S.B., and L.A. Kszos. 2005. Development of switchgrass (Panicum virgatum) as a bioenergy feedstock in the United States. Biomass Bioenerg. 28:515-535.

Missaoui, A.M., A.H. Paterson, and J.H. Bouton. 2005. Investigation of genomic organization in switchgrass (Panicum virgatum L.) using DNA markers. Theor. Appl. Genet. 110:1372-1383.

Missaoui, A.M., A.H. Paterson, and J.H. Bouton. 2006. Molecular markers for the classification of switchgrass (Panicum virgatum L.) germplasm and to assess genetic diversity in three synthetic switchgrass populations. Genet. Resour. Crop Evol. 53:1291-1302.

Moore, K.J., L.E. Moser, K.P. Vogel, S.S. Waller, B.E. Johnson, and J.F. Pedersen. 1991. Describing and quantifying growth stages of perennial forage grasses. Agron. J. 83:1073-1077.
Perrin, R.K., K.P. Vogel, M.R. Schmer, and R.B. Mitchell. 2008 Farm-scale production cost of switchgrass for biomass. BioEnerg. Res. 1:91-97.

SAS Institute. 2002. SAS. Version 9.1.3 PC. SAS Inst., Cary, NC. Schmer, M.R., K.P. Vogel, R.B. Mitchell, L.E. Moser, K.M. Eskridge, and R.K. Perrin. 2006. Establishment stand thresholds for switchgrass grown as a bioenergy crop. Crop Sci. 46:157-161.

Schmer, M.R., K.P. Vogel, R.B. Mitchell, and R.K. Perrin. 2008. Net energy of cellulosic ethanol from switchgrass. Proc. Natl. Acad. Sci. USA 105:464-469.

Vogel, K.P. 1987. Seeding rates for establishing big bluestem and switchgrass with pre-emergence atrazine applications. Agron. J. 79:509-512.

Vogel, K.P. 2000. Improving warm-season grasses using selection, breeding, and biotechnology. p. 83-106. In K.J. Moore and B. Anderson (ed.) Native warm-season grasses: Research trends and issues. CSSA Spec. Publ. 30. CSSA and ASA, Madison, WI.

Vogel, K.P. 2004. Switchgrass. p. 561-588. In L.E. Moser, L. Sollenberger, and B. Burson (ed.) Warm-season $\left(\mathrm{C}_{4}\right)$ grasses. Agron. Monogr. 45. ASA, CSSA, and SSSA, Madison, WI.

Vogel, K.P., J.J. Brejda, D.T. Walters, and D.R. Buxton. 2002. Switchgrass biomass production in the Midwest USA: Harvest and nitrogen management. Agron. J. 94:413-420.

Vogel, K.P., and B. Burson. 2004. Breeding and genetics. p. 51-96. In L.E. Moser, L. Sollenberger, and B. Burson (ed.) Warmseason $\left(\mathrm{C}_{4}\right)$ grasses. ASA Monogr. 45. ASA, CSSA, and SSSA, Madison, WI.

Vogel, K.P., A.A. Hopkins, K.J. Moore, K.D. Johnson, and I.T. Carlson. 1996. Registration of 'Shawnee' switchgrass. Crop Sci. 36:1713.

Vogel, K.P., and J.F. Pedersen. 1993. Breeding systems for crosspollinated perennial grasses. Plant Breed. Rev. 11:251-274.

Vogel, K.P., M.R. Schmer, and R.B. Mitchell. 2005. Plant adaptation regions: Ecological and climatic classification of plant materials. Rangeland Ecol. Manage. 58:315-319.

Weaver, J.E. 1968. Prairie plants and their environments. Univ. of Nebraska Press, Lincoln. 